\author{
Case Study
}

\title{
DIAGNOSTIC AND THERAPEUTIC APPLICATION OF AYURVEDIC THERAPIES IN RAKTAPRADAR AFTER RAJONIVRITTI: A CASE STUDY
}

\section{Tomar Pravesh ${ }^{1 *}$, Lal Sudeep ${ }^{2}$, Jugran Sonali ${ }^{3}$}

${ }^{*}$ Professor, ${ }^{3}$ PG Scholar, Dept. of Prasuti Tantra and Stree rog Vibhag, Rishikul Campus, Uttarakhand Ayurveda University, Haridwar, India.

${ }^{2}$ Lecturer, Dept. of Swasthvritta Vibhag, SKD State Ayurvedic College, Muzaffarnagar.

\section{Article info \\ Article History: \\ Received: 01-07-2021 \\ Revised : 14-07-2021 \\ Accepted: 22-07-2021 \\ Published: 25-08-2021}

\section{ABSTRACT}

Post-menopausal bleeding is reported in about 4 to 11 percent of women. Its causes include several factors which may be benign or malignant. Benign factors can be managed at outpatient level and Ayurvedic procedures of Prakshalana and Pichu can be its alternative for management. Present case study is of post-menopausal bleeding where by the use of these Ayurvedic procedures, first the cause of bleeding was revealed and then, after removal of factor, it provided compete relief from bleeding. Thus, Ayurvedic procedures of Prakshalana and Pichu had two benefits in this case- diagnostic as well as therapeutic.

KEYWORDS: Post menopausal bleeding, Rajonivritti, Prakshalana.

\section{INTRODUCTION}

Menopause is the point in time of permanent cessation of menstruation due to loss of ovarian activity. It is declared at a point in time after 1 year of cessation of menstruation.[1] After a woman is postmenopausal further vaginal bleeding is no longer considered normal, the differential diagnosis of which includes many benign and malignant conditions.

Vaginal bleeding is reported in about $4-11 \%$ of post-menopausal women. ${ }^{[2]}$

The most common cause of post-menopausal bleeding (PMB) is atrophy, either of the endometrium or vaginal mucosa. Other causes are endometrial hyperplasia, endometrial or cervical polyps and submucous leiomyomas, cervicitis, cervical cancer, endometritis, etc. ${ }^{[3]}$

Diagnosis of post-menopausal bleeding is crucial as majority cases are of carcinoma. Malignancy must be ruled out in every case of PMB through proper assessment. Examination is the first and important step in such cases to evaluate the cause.

\begin{tabular}{|l|l|}
\hline \multicolumn{3}{|c|}{ Access this article online } \\
\hline Quick Response Code & https://doi.org/10.47070/ijapr.v9i7.1956 \\
\hline & $\begin{array}{l}\text { Published by Mahadev Publications (Regd.) } \\
\text { publication licensed under a Creative } \\
\text { Commons Attribution-NonCommercial- } \\
\text { ShareAlike 4.0 International (CC BY-NC-SA } \\
\text { 4.0) }\end{array}$ \\
\hline
\end{tabular}

Malignant conditions need management at super specialised hospitals. Benign conditions such as atrophy, polyps, cervicitis can be managed at outpatient level. Hormone replacement therapy along with symptomatic treatment and steroids use is the line of treatment for bleeding after menopause. Simple Ayurvedic procedures such as Yoni Prakshalana (douching) and Yoni Pichu (tamponing) are the alternatives for the management which are cost effective, convenient to the patient and provide the needed benefit without any steroid use.

......तद् वर्षाद् द्वादशादूध्व्व याति पंचाशत :क्षयम् ॥ (सु.सू. 14/6) ${ }^{[4]}$

Menopause has been mentioned as Rajonivritti in Ayurveda. Its age has been mentioned as 50 years after which menses does not occur. It has been described as a stage of women's life.

Changes after menopause has not been mentioned particularly in texts, as it has no significance in reproduction

Any abnormal bleeding from vagina can be related with the description of Rakta Pradar in Ayurveda.

रज :प्रदीर्यते यस्मात प्रदरस्तेन स स्मृत :॥ (च .चि. 20/30.9) [5]

Acharya Charaka has described Pradara as excessive menstrual flow.

यदा तु तच्छोणितं दुष्टमार्गं प्रतिपद्यते तदा स्रीणां प्रदरो भवति ॥ (भे .शा . 6/5) ${ }^{[6]}$ 
According to Bhel Samhita, when the blood is seen through abnormal passages, it is termed as Pradara.

अतिप्रसंगेनानर्तावृतो वा तदेवासृगदर प्रदर व्यापद च रक्तयोनिसज्ञा लभते । (अ .स .शा .1/5) [7]

In Ashtang Samgrah, Asrigdar, Pradara and Raktayoni has been referred as excess menstrual flow or bleeding apart from regular time.

\section{तदेवातिप्रसंगेन प्रवृत्तमनृतावपि।}

असृग्दर विजानीयादतोअन्यद्रक्तलक्षणात ॥ (सु .शा .20/2)[8]

Acharya Sushruta has stated that when Artava is seen at times other than menstrual phase and is not similar to menstrual blood, it is called Asrigdara or Raktapradara. Atiprasangen can be related to frequent intercourse or for prolonged period or excessive amount.

Pradar or Asrigdar has been related to dysfunctional uterine bleeding in texts as it has been mentioned together with description of Artava.

It can also be related to any type of abnormal vaginal bleeding as it differs from normal menstrual flow in terms of features, time period, duration and amount.

\section{Case Summary}

A 52 years lady visited the OPD with complain of moderate bleeding per vaginum for 2-3 days. Her menopause occurred 3 years back. She was having history of breast carcinoma, so was anxious about her complain.

On per speculum examination, along with white discharges covering the cervix, congested areas were visible over cervix with a ridge like growth.

She was advised Yoni Prakshalan with Triphala kwatha and Yoni Pichu with Jatyadi taila for 7 days, after which the site of bleeding was revealed as from the base of cervical polyp. She was advised for polypectomy.

Again after polypectomy, she had bleeding per vaginum. Examination revealed inflamed with hardened tissue at the site of surgery. Rest of the cervix was healthy. Yoniprakshalan and Yoni pichu were started, after which her symptoms subside.

\section{Past history}

- Operated for breast carcinoma (4 years back)

- Patient had visited the OPD with the same complain 1 year back. Per speculum examination revealed hypertrophied cervix with very insignificant ridge like growth over cervix. PAP smear was normal. Oral medicines were prescribed to her after which her bleeding stopped. Again with same complain, patient visited the hospital after 8-10 months.

Married life - Widow since 8 years

Obstetric history- $\mathrm{P}_{2+0}$; both vaginal delivery

\section{Investigations}

1.USG Lower abdomen (02/02/2021)-Mild cervicitis with hypoechoic focus of $5.2 \times 4.9 \mathrm{~mm}$ in posterior lip of cervix, likely inflammatory changes.

\section{Blood investigations $(2 / 12 / 2019)$}

Haemoglobin- $13.3 \mathrm{~g} / \mathrm{dl}$

TLC- 5.95 x 1000/micro L

RBC- 4.55 millions/ cumm

Platelet - 2.60 lakh/cumm

Neutrophil- $70.7 \%$,

Lymphocyte- $26.2 \%$,

Eosinophil- 1.2\%,

Monocyte- $1.7 \%$

Blood sugar (F)- $124 \mathrm{mg} / \mathrm{dl}$

Blood sugar (PP) $-149 \mathrm{mg} / \mathrm{dl}$

LH- $28.03 \mathrm{mIU} / \mathrm{m}$,

FSH- $66.76 \mathrm{mIU} / \mathrm{m}$,

\section{Urine routine examination}

Colour- yellow, glucose- nil, protein- nil, specific gravity- 1.025 , pH- 6 , pus cells- $2-3$, epithelial cellsfew

\section{PAP smear (15/04/2019)}

Atrophic chronic endocervicitis with NILM (Non neoplastic findings).

\section{Treatment Procedure}

Patient was given lithotomy position. Triphala kwatha Yoni Dhawana was done by yonidhawan patra. Then Jatyadi oil Pichu (tamponing) was kept high up in the vagina or 2-3 hours. Procedure was repeated for continuous 7 days.

\section{Quantity}

Triphala kwatha- $100 \mathrm{ml}$

Jatyadi oil- $2 \mathrm{ml}$

\section{Drugs used}

1)Triphala is an easily available, cost effective drug. It is the combination of three fruits of Haritaki (Terminalia chebula), Bibhitak (Terminalia bellerica) and Amalaki (Emblica officinalis).

These three drugs have been mentioned in Mustadi gana of Sushruta which has property of Yonidoshar i.e. cure disorders related to vagina and cervix [9].

Triphala is anti-inflammatory, antiviral, anti-bacterial, antioxidant, improves circulation and possesses astringent property.

According to Ashtanga Hridya, it has Vranaropan properties along with promoting eye health and curing skin diseases.[10]

\section{Preparation of kwatha:}

1-part Triphala + 16-part water, boiled up to $1 / 8$ part remaining. ${ }^{[11]}$ 
This procedure is mentioned for oral use. For external use, 10 gm of Triphala powder is mixed with $100 \mathrm{ml}$ water and boiled for 3-4 minutes.

2) Jatyadi taila is advised for local application in the management of Vrana. In Yogratnakara, it has been mentioned in Sadyovranachikitsa and has been indicated for Vishaj vrana, Sphot (boils), Kandu (itching), Dagdh (burns), cuts over skin and heal any wound by virtue of Shodhana and Ropana properties [12].

Acharya Sharangdhar has described its uses in Nadi vrana (sinus ulcer), Kachhu (dermatitis), Dagdha (burns) and Dusht vrana. [13]

\section{Ingredients and properties: [14]}

- Haridra rhizome- (Curcuma longa): Antioxidant, anti-inflammatory, anti-bacterial and anti-fungal effects.

- Daruharidra seed- (Berberis aristata): Antibacterial, antifungal, anti-inflammatory, analgesic.

- Jatipatra leaf- (Jasminum auriculatum): It is one of the most important ingredients. Juice of leaves is found beneficial in wound healing. Anti-oxidant and anti-bacterial activities. The plant reports antioxidant and antibacterial activities of the essential oils. Its other benefits are antiseptic, antihelminthic, suppurative, skin disease, wound, corn, anti-ulcer, cytoprotective, wound healing and antiacne activity.

- Neem patra- Azadirachta indica: Its leaves, bark extracts and oil are used for therapeutic effects. Its oil suppresses several species of pathogenic bacteria.

- Patola plant- Trichosanthes dioica: Used for fever, skin infections and wounds.

- Karanja leaf- Pongamia glabra: Its leaves are effective as medicated bath and rheumatic pains;roots have antimicrobial activity.

- Yashtimadhu root- Glycyrrhiza glabra: It has many actions such as anti-inflammatory, anti-viral, anti-microbial, antioxidative effects.

- Kushtha root-Saussurea lappa: The roots possess carminative, analgesic, antihelminthic activity.

- Katuki rhizome- Picrorhiza kurroa: Works as laxative, inflammation and skin disorders.

- Manjishtha root- Rubia cordifolia: Antiinflammatory, wound healer, astringent, blood purifier, anti-microbial and anti-allergic properties. It is very useful in most skin disorders. External used increases peripheral circulation, oozing skin lesions and pressure sores.

- Padmaka wood- Prunus cerasoides: Crushed stem bark is applied on injuries.

- Lodhra bark- Symplocos racemose: it is used as menstrual regulator, astringent, anti-inflammatory, hypothermic, haemostatic and anticancer properties.

- Abhaya plant- Terminalia chebula: It has extra ordinary healing power, besides having anti-oxidant and anti-carcinogenic properties.

- Neelotpala flower- Nymphaea stellate: Vegetable flowers and rhizomes have astringent, demulcent and antiseptic action.

- Shweta sariva root- Hemidesmus indicus: Root is used for skin diseases.

- Karanja seed- Pongamia pinnata: It leaves have anti-microbial, anti-inflammatory and relieves itching. Seed oil is wound healer and analgesic.

- Wax: It is obtained from the comb of bees Apis indica.

- Tutth- copper: It has anti-microbial and scraping activity.

- Til tail- Sesamum indicum: Have anti-oxidant and health promoting activity, analgesic, wound healing, haemostatic.

Preparation of Oil: The ingredients are taken in equal quantity, Til tail is taken 4 times the Kalka and water is taken 16 times the Kalka. Then the oil is prepared. [15]

\section{DISCUSSION}

सर्वत :सुविशुद्धाया :शेष :कर्म विधीयते।

बस्त्यभंगपरिषेकप्रलेपपिचुधारणम ॥ (अ .स .उ 53/39) [16]

After Shodhana Chikitsa in woman with Yonivyapada, local treatment in form of Vasti, Abhyanga, Parisheka, Pralepa and Pichu dharana has been advised.

स्रीणा स्रेहादियुक्ताना चतस्रष्वार्तवार्तिषु। कुर्यात्कल्कान पिचूश्वापि पथ्यान्याचमनानि च ॥ (सु .शा 15/2)[17]

After Shodhana Chikitsa, for purification of Yoni and for Artavadushti, Kalka, Pichu and Prakshalan has been advised.

Treatment with local therapies has been mentioned in context of various Yoniroga. Drugs are absorbed better by local treatment and produce quick benefits. Yoni parishek/Prakshalana and Yoni Pichu are therapeutic procedures in Ayurveda. These are generally done to cure infectious condition of lower reproductive tract.

Present case study shows their role as a diagnostic tool also. Triphala used for Prakshalan improves blood supply, cures infection and removes discharges due to its astringent and antimicrobial activity. Jatyadi tail pichu promotes healing by subsiding inflammation and removing dead tissues. Congestion and discharges from cervix were cured which were concealing the site of bleeding i.e., cervical polyp. Thus, local therapy here, by their actions, provided both therapeutic and diagnostic benefits.

After polypectomy, inflammation of cervix produced bleeding per vaginum. Again, Triphala kwath 
Prakshalan and Jatyadi oil Pichu were advised which promotes healthy tissue growth by improving circulation and anti-inflammatory activity.

\section{CONCLUSION}

Sthanik chikitsa in Ayurveda is well established for therapeutic results. Their mode of action varies with the drugs and type of procedure used. Given study illuminates their aspect in diagnosis too. In the first visit, the cause of bleeding was not revealed due to concealment by discharges, congestion and inflamed tissues. After the procedures, discharges and inflammation subsided exposing the cervical polyp. Thus, it helped in timely diagnosis ruling out other causes and prevented the patient from unnecessary hospital visits and examinations.

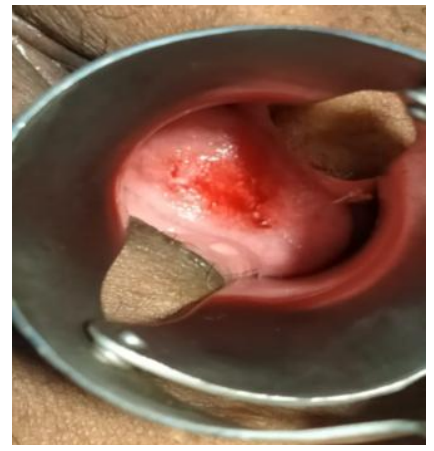

Figure 1: Per speculum examination after polypectomy

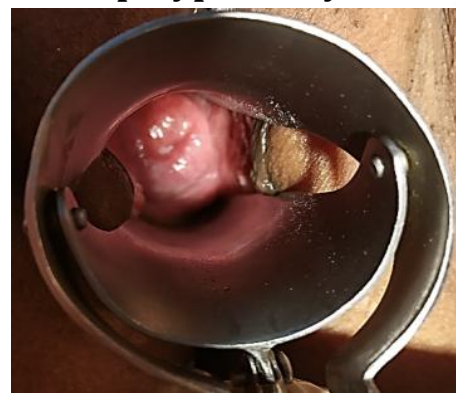

Figure 2: Per speculum examination after Yoni prakshalana and Pichu

\section{REFRENCES}

1. Arup Kumar Majhi, Bedside clinics in Gynecology, Jaypee publishers, Chapter 20. Page 610.

2. Sharon Sung, Aaron Abramovitz. Postmenopausal Bleeding. Treasure Island (FL): StatPearls Publishing; 2021 Jan. https://www.ncbi.nlm. nih.gov/books/NBK562188
3. D C Dutta's textbook of Gynaecology including contraception, sixth edition, chapter 33, page 535.

4. Kaviraja Ambika dutta Shastri Sushruta samhita, Edited with Ayurveda tattva Sandipika, Sutrasthana 14/6.

5. Pt.Kasinath shastri and Dr. Gorakhanatha Chaturvedi Charaka Samhita with Vidyotini Hindi Commentary, Chikitsasthana 30/201.

6. Prof. Premwati Tewari Ayurvediya Prasuti tantra evum Stree rog, second part, chapter 2, page 174.

7. Prof. K.R. Srikantha Murthy Astanga Samgraha of Vagbhatta, Sharirsthana 1/5.

8. Kaviraja Ambika Dutta Shastri Sushruta samhita, Edited with Ayurveda tattva Sandipika, Sharirsthana $2 / 20$.

9. Kaviraja Ambika Dutta Shastri Sushruta samhita, Edited with Ayurveda tattva Sandipika, Sutrasthana 38/45.

10. Dr.Brahmanand Tripathi, Astanga Hrdayam of Srimadvagbhata, Edited with Nirmala Hindi Commentary, Sutrasthana 6/159.

11. Dr.Shailja Srivastava, Sarangdhar Samhita of Acharya Sharngadhar, Jiwanprada Hindi commentary, Madhyam khand, 2/1.

12. Vaidya Laksmipati Sastri, Yogratnakara with Vidyotini Hindi commentary, edited by Bhisagratna Brahmasankar Sastri, Sadyovranachikitsa.

13. Dr.Shailja Srivastava, Sharangdhar Samhita of Acharya Sharngadhar, Jiwanprada Hindi commentary, Madhyam khand, 9/169,170,171, 172.

14. Singh Baljinder, Jindal Neerja, Bansal Renu. Antimicrobial potential of polyherbo-mineral formulation Jatyadi Taila-A review. International Journal of Research in Ayurveda and Pharmacy 2(1):151-158

15. Dr.Shailja Srivastava Sharangdhar Samhita of Acharya Sharngadhar, Jiwanprada hindi commentary, Madhyam khand, 9/1.

16. Prof. K.R. Srikantha Murthy, Astanga Samgraha of Vagbhatta, Uttartantra 39/53.

17. Kaviraja Ambika dutta Shastri Sushruta samhita, Edited with Ayurveda Tattva Sandipika, Sharirsthana 2/15.

\begin{abstract}
Cite this article as:
Tomar Pravesh, Lal Sudeep, Jugran Sonali. Diagnostic and Therapeutic Application of Ayurvedic Therapies in Raktapradar after Rajonivritti: A Case Study. International Journal of Ayurveda and Pharma Research. 2021;9(7):31-34. https://doi.org/10.47070/ijapr.v9i7.1956
\end{abstract}

Source of support: Nil, Conflict of interest: None Declared

*Address for correspondence
Dr. Jugran Sonali
PG Scholar,
Prasuti tantra and Stree rog
vibhag, Rishikul campus,
Uttarakhand Ayurveda University,
Haridwar.
Email:
sonali1992jugran@gmail.com

Disclaimer: IJAPR is solely owned by Mahadev Publications - dedicated to publish quality research, while every effort has been taken to verify the accuracy of the content published in our Journal. IJAPR cannot accept any responsibility or liability for the articles content which are published. The views expressed in articles by our contributing authors are not necessarily those of IJAPR editor or editorial board members. 